\title{
Opere Over Kanseri Hastalarında Preoperatif Yüksek CA125 Değerinin Postoperatif Normal Sunırlara Dönmesinin Klinik Önemi
}

\section{Clinical Significance of Postoperative CA125 Level Normalization in Operated Ovarian Cancer Patients with High Preoperative Levels}

\author{
Umut Varol ${ }^{1}$, Nagihan Akkaş², Utku Oflazoğlu ${ }^{3}$, Tarık Salman³, Halil Taşkaynatan ${ }^{3}$, Seray Saray $^{3}$, Yaşar Yıldız $^{3}$, \\ Ahmet Alacacıoglu ${ }^{3}$, Yüksel Küçükzeybek ${ }^{3}$, Mustafa Oktay Tarhan ${ }^{4}$ \\ ${ }^{1}$ İzmir Demokrasi Üniversitesi, Tıbbi Onkoloji Bilim Dalı, İzmir \\ ${ }^{2}$ İzmir Katip Çelebi Üniversitesi Atatürk Eğitim ve Araştırma Hastanesi, İç Hastalıkları Kliniği, İzmir \\ ${ }^{3}$ İzmir Katip Çelebi Üniversitesi Atatürk Eğitim ve Araştırma Hastanesi, Tıbbi Onkoloji Kliniği, İzmir \\ ${ }^{4}$ İzmir Dokuz Eylül Ǘniversitesi Onkoloji Enstitüsü, İzmir
}

e-mail: varolumut@yahoo.com,drnghnkks@gmail.com,utku.oflazoglu@saglik.gov.tr,drtariksalman@gmail.com, haliltaskaynatan@gmail.com, serayyaras@hotmail.com,dryasar2706@yahoo.co.uk, Ahmet.alacac1oğlu @ saglik.gov.tr,drzeybek@yahoo.com, motarhan@yahoo.com

ORCID: 0000-0002-4669-2052

ORCID: 0000-0002-6787-8331

ORCID: 0000-0002-6819-5831

ORCID: 0000-0001-7911-6978

ORCID: 0000-0002-3671-6540

ORCID: 0000-0002-6512-9842

ORCID: 0000-0002-2912-3835

ORCID: 0000-0003-3428-5932

ORCID: 0000-0003-3173-7999

ORCID: 0000-0002-1380-9736

*Sorumlu yazar/ Corresponding Author: Umut Varol

Gönderim Tarihi / Received: 27.05.2020

Kabul Tarihi / Accepted: 20.10.2020

DOI: $10.34087 /$ cbusbed.743230

\section{$\ddot{\mathbf{O} z}$}

Giriş ve Amaç CA125, over kanseri hastalarında gerek tanı aşamasında gerekse tedavi sonrası takiplerde tümör belirteci olarak kullanılmaktadır. Biz de çalışmamızda preoperatif serum CA125 değeri yüksek olan over kanseri hastalarında operasyondan sonraki değerlerinin normale dönüp dönmemesinin nüks riskini belirleme ve nükse kadar geçen süre açısından önemini araştırdık.

Gereç ve Yöntemler: Çalışmamızda 2005 - 2013 yılları arasında İzmir Katip Çelebi Üniversitesi Atatürk Eğitim ve Araştırma Hastanesi Tıbbi Onkoloji Kliniğinde opere over kanseri tanısıyla takip ve tedavi edilen hastalar retrospektif olarak taranmıştır. CA125 sınır değeri olarak hem $35 \mathrm{IU} / \mathrm{ml}$ hem de $65 \mathrm{IU} / \mathrm{ml}$ kullanılarak iki farklı analiz yapılmıştır. Bulgular: Çalışmamıza bazal CA125 değeri yüksek olan (sınır değer >35 IU/ml ve $65 \mathrm{IU} / \mathrm{ml}$ alındığında) sırasıyla 132 ve 119 hasta alınmıştır. Preoperatif CA125 değeri yüksek olup postoperatif normale gelen hastaların sayısı sırasıyla 54 ve 58 iken bu değeri normalleşmeyen hastaların sayısı 78 ve 61'dir. Her iki CA125 sınır değeri için, postoperatif CA125 değeri normalleşenlerle normalleşmeyen hastalarda hem nükse kadar geçen süre (32 aya karş1 18 ay p:0,015 - 32 aya karş1 17 ay p:0,001) hem de tüm sağkalım açısından (108 aya karşı 36 ay p:0,015 - 89 aya karş1 33 ay p:0,000) istatistiksel anlamlı fark saptanmıştır. 
Sonuç: Opere over kanseri hastalarından bazal CA125 değeri yüksek saptanan hastalarda ameliyat sonrasındaki düşüşü değerlendirip, bu değerin normal sınırlara düşüp düşmemesine göre nüks süreci hakkında fikir sahibi olunabilinir.

Anahtar kelimeler: CA125, Nüks riski, Over kanseri, Perioperatif,

\begin{abstract}
Objective: CA125 is a commonly used tumor marker in ovarian cancer patients for both diagnostic evaluation and follow-up period. In this study, we investigated the clinical importance of postoperative serum CA125 level normalization in ovarian cancer patients with high preoperative levels in terms of recurrence risk and disease free survival.

Materials and Methods: We retrospectively analyzed operated ovarian cancer patients who were followed up in medical oncology clinic of Izmir Katip Celebi University Ataturk Training and Research Hospital between years 2005 - 2013. Two different analyses were done according to different CA125 cut-off levels; $35 \mathrm{IU} / \mathrm{ml}$ and $65 \mathrm{IU} / \mathrm{ml}$.

Results: There are 132 and 119 patients who had basal CA125 levels above normal (cut-off levels were $>35$ IU/ml and $65 \mathrm{IU} / \mathrm{ml}$ respectively). The number of patients who had normalized CA125 levels after surgery was 54 and 58 , and who had still high levels was 78 and 61, respectively. For both CA125 cut-off values, there were statistically significant differences in disease free survival (32 month vs. 18 month p:0.015 - 32 month vs. 17 months p:0.001) and overall survival (108 month vs. 36 month p:0.015 - 89 month vs. 33 month p:0.000) between patients with normalized and not normalized postoperative CA125 levels.

Conclusion: In operated ovarian cancer patients, who had high preoperative CA125 levels, the decrease in this value postoperatively must be evaluated and normalization of this tumor marker may give us an idea about the recurrence of the disease.
\end{abstract}

Keywords: CA125, Ovarian cancer, Perioperative, Recurrence risk

\section{Introduction}

CA125 values are high in $50 \%$ of newly diagnosed early stage epithelial ovarian cancer patients and $80 \%$ of advanced stage patients, which was more prominent especially in ovarian serous tumors [1,2]. However, it is not possible to use the CA125 marker alone as a diagnostic test due to its low sensitivity and specificity. Therefore, its use in ovarian cancer is generally accompanied by clinical evaluation and imaging methods. Surgical cytoreduction and ascites drainage reduce the level of CA125, while peritoneal damage and surgical intervention increase its level $[3,4]$.

In epithelial ovarian cancer patients, the CA 125 tumor marker is used to evaluate the treatment response and monitor the status of the disease, especially if it is high at the time of diagnosis [5]. There are many studies investigating the relationship between perioperative CA125 levels and survival in epithelial ovarian cancer patients [6-10]. However, in patients with high preoperative CA125 levels, there are limited number of studies investigating CA125 change after surgery and its relation with relapse risk and survival. In addition, the relationship between the reduction of CA125 level and residual tumor burden in the early postoperative period is controversial [11].

The aim of this study is to evaluate CA125 change postoperatively in newly diagnosed ovarian cancer patients who have not received any systemic treatment before. The decline in postoperative CA125 levels of the patients with high baseline levels was investigated, and the relapse status and time to relapse of those patients whose CA125 levels returned to normal limits after operation or not were compared.

\section{Materials ve Methods}

\section{Patients selection}

In our study, patients who were followed and treated in our medical oncology clinic between years 2005 and 2013 with the diagnosis of operated ovarian cancer were evaluated. The upper limit value of CA125 is used as 35 $\mathrm{IU} / \mathrm{ml}$ which is accepted as the cut-off value in the literature. The serum level of CA125 can vary with the menstrual cycle and may be above $35 \mathrm{IU} / \mathrm{ml}$ in some benign diseases. Therefore, $65 \mathrm{IU} / \mathrm{ml}$ is also used as a cutoff value, especially to increase specificity. As a result, patients were evaluated and analyzed separately according to both cut-off values $(35 \mathrm{IU} / \mathrm{ml}, 65 \mathrm{IU} / \mathrm{ml})$. CA125 values of all patients were evaluated in the hospital where the study was conducted. Informed consent was obtained from all the participants and the institution's ethics committee approved the study.

Since only the patients with high preoperative CA125 levels (> 35 or $65 \mathrm{IU} / \mathrm{ml}$ ) were included in the study, patients were then evaluated according to whether their CA125 levels returned to normal limits after the surgery or not. Patients with normal baseline CA125 levels and no recorded preoperative or postoperative CA125 levels were excluded. CA125 values of the patients were studied in serum samples before and after the operation by the electrochemiluminescence enzyme immunoassay method (Roche Diagnostics, Modular analytics E170, Germany) on the hormone analyzer.

All of the ovarian cancer patients in this study had primary staging surgery (total extra facial hysterectomy, bilateralsalpingo-oophorectomy, pelvic and para-aortic lymph node dissection). Patients who underwent curative or optimal $(\mathrm{R} 0, \mathrm{R} 1)$ resection were included in the study, while patients who underwent suboptimal (R2) resection, tumor-debulking surgery, or only biopsy and those who were operated after neoadjuvant chemotherapy were 
excluded in the study. The patients' demographic features, pathological subtypes, histological grades, surgical stages, adjuvant treatments, the locations of these regions in patients who developed recurrence or metastasis and the treatments they received in metastatic state were examined. The current FIGO surgical staging system (2017) was used in the staging of ovarian cancer patients.

Statistical Analysis

Overall-survival (OS) was defined as the time from the pathological diagnosis to the patient death or last oncological follow-up. Disease-free survival (DFS) was defined as the time from pathological diagnosis to first recurrence (local, regional, or distant) or death by any cause before disease progression. Qualitative variables have been presented as frequencies and percentage while quantitative data are presented as means, medians, and ranges. Our parameters which are not normally distributed were evaluated with Kruskall Wallis analysis and Mann Whitney U test; Student's t test was used for parameters with normal distribution. In the comparison of qualitative data, Chi Square test was used. For survival analysis Kaplan-Meier method was used and the survival of the groups was compared with the log-rank test. All statistical tests were two-sided, and $\mathrm{p}$ value $<0.05$ was considered statistically significant. SPSS version 20.0 (SPSS Inc., Chicago, IL) was used for all statistical evaluation of the data.

\section{Results}

There were a total of 132 patients with high basal CA125 levels $(>35 \mathrm{IU} / \mathrm{ml})$ in our study. While the number of patients whose CA125 levels returned to normal limits after operation is $54(41 \%)$, the number of patients whose CA125 levels did not return to normal limits after operation is $78(59 \%)$. When the cut-off value for baseline CA125 was taken as $65 \mathrm{IU} / \mathrm{ml}$, the preoperative CA125 level was found high in 119 patients. Above them, the number of patients whose CA125 levels normalized postoperatively was $58(49 \%)$, while the number of patients whose CA125 levels did not normalize postoperatively was $61(51 \%)$. The median patient age was 56 years, ranging from 33 to 84 .

When we evaluate patients according to their stages; 21 patients are stage I, 12 patients are stage II and 99 patients are stage III. While serous carcinoma was the most common pathology in our ovarian cancer patients (n: 80, $60.6 \%$ ), clear cell carcinoma were detected in 12 patients, endometrioid carcinoma in 10 patients, mucinous carcinoma in 6 patients, mixed pathology in 18 patients and other rare pathologies in 6 patients. Grade 3 differentiation was observed in 87 patients, grade 2 in 25 patients, and grade 1 in 20 patients. R0 resection was performed in 90 patients $(68.1 \%)$, while $\mathrm{R} 1$ resection was performed in 42 patients $(31.9 \%)$ (Table 1$)$.

When $35 \mathrm{IU} / \mathrm{ml}$ was taken for the CA125 cut-off value, recurrence or metastasis was developed in 34 patients $(63 \%)$ and 60 patients $(76.9 \%)$ among the patients whose postoperative CA125 levels returned to normal limits or nor respectively (p: 0.08 ). When the CA125 cut-off value
Table 1. Tumor Characteristics

$\begin{gathered}\text { Number } \\ \text { of } \\ \text { Patients }\end{gathered}$
(In)

Characteristics

(n)

\begin{tabular}{|c|c|c|}
\hline Tumor Grade & & \\
\hline Grade I & 87 & 65.9 \\
\hline Grade II & 25 & 18.9 \\
\hline Grade III & 20 & 15.2 \\
\hline \multicolumn{3}{|l|}{ Disease Stage } \\
\hline Stage I & 21 & 15.9 \\
\hline Stage II & 12 & 9.1 \\
\hline Stage III & 99 & 75.0 \\
\hline \multicolumn{3}{|l|}{ Surgical Border } \\
\hline R0 & 90 & 68.1 \\
\hline $\mathrm{R} 1$ & 42 & 31.9 \\
\hline
\end{tabular}

\begin{tabular}{lcc} 
Tumor Pathology & & \\
Serous & 80 & 60.6 \\
Clear cell & 12 & 9.1 \\
Endometrioid & 10 & 7.4 \\
Musinous & 6 & 4.6 \\
Mix & 18 & 13.7 \\
Rare pathologies & 6 & 4.6 \\
\hline
\end{tabular}

\begin{tabular}{llll}
$\begin{array}{l}\text { Serous and } \\
\text { Pathology }\end{array}$ & Non-serous & & \\
\cline { 1 - 1 } Serous & & \\
Non-serous & 96 & 72.7 \\
\hline
\end{tabular}

was taken as $65 \mathrm{IU} / \mathrm{ml}, 35$ patients $(60.3 \%)$ among the patients whose CA125 levels normalized postoperatively and 51 patients $(83.6 \%)$ among the patients whose CA125 levels did not normalize postoperatively developed relapses or metastases (p:0.01). When these two groups were compared in terms of R1 surgical margin, it was observed that there was statistically significant more R1 surgery in the group whose postoperative CA125 value did not return to normal ( $\mathrm{p}$ : 0.043). Age, disease stage and tumor pathological features of the two groups of patients were compared and no statistically significant difference was found.

The median disease-free survival of the patients was 20 months (16-23). When the two groups of patients (according to CA125 cut-off value $35 \mathrm{IU} / \mathrm{ml}$ ) were compared in terms of time to relapse or metastasis, the median DFS of the patients whose CA125 values were normalized after the operation was found to be 32 months (11-52) and in patients whose CA125 values were did not normalize after the operation DFS was found to be 18 months (15-20) (p:0.015) (Figure 1). 


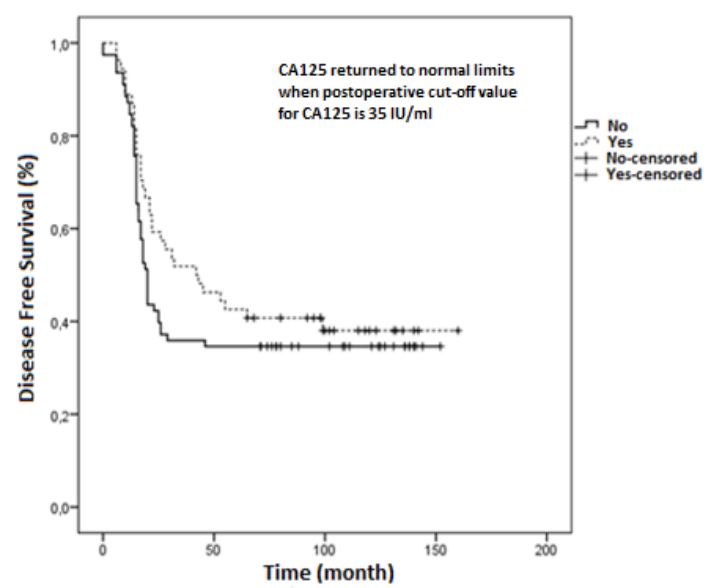

Figure 1. Disease free survival analysis when postoperative cut-off value for CA125 is $35 \mathrm{IU} / \mathrm{ml}$.

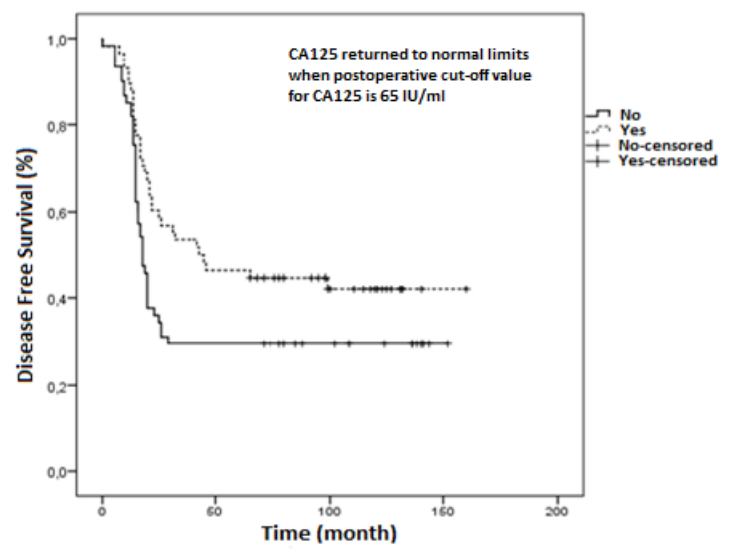

Figure 2. Disease free survival analysis when postoperative cut-off value for CA125 is $65 \mathrm{IU} / \mathrm{ml}$.
When $65 \mathrm{IU} / \mathrm{ml}$ was taken for the CA125 cut-off value, the median DFS was 32 months (8-55) in patients with normalized postoperative CA125 value, whereas 17 months (14-19) in patients with non-normalized postoperative CA125 value (p:0.001) (Figure 2; Table 2). The median overall survival of the patients was 58 months (41-74). When the two group of patients (according to CA125 cut-off value $35 \mathrm{IU} / \mathrm{ml}$ ) were compared in terms of survival, the median OS of the patients whose CA125 values were normalized after the operation was found to be 108 months (61-133) and in patients whose CA125 values were did not normalize after the operation OS was found to be 36 months (1952) (p:0.015) (Figure 3). When $65 \mathrm{IU} / \mathrm{ml}$ was taken for the CA125 cut-off value, the median OS was 89 months (36-108) in patients with normalized postoperative CA125 value, whereas 33 months (28-37) in patients with non-normalized postoperative CA125 value (p:0.000) (Figure 4; Table 2).

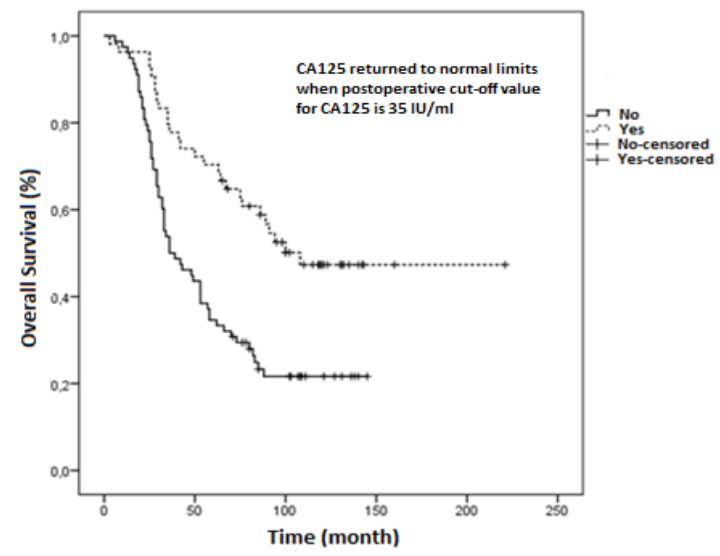

Figure 3. Overall survival analysis when postoperative cut-off value for CA125 is $35 \mathrm{IU} / \mathrm{ml}$.

Table 2. Survival analysis of the patients whose CA125 levels returned to normal limits after operation or not

\begin{tabular}{|c|c|c|c|c|}
\hline & $\begin{array}{c}\text { Disease Free } \\
\text { Survival } \\
\text { (months) } \\
\end{array}$ & $\mathbf{p}$ & $\begin{array}{c}\text { Overall } \\
\text { Survival } \\
\text { (months) } \\
\end{array}$ & $\mathbf{p}$ \\
\hline \multicolumn{5}{|l|}{ Cut-off value for CA125 is $35 \mathrm{IU} / \mathrm{ml}$} \\
\hline $\begin{array}{l}\text { Patients whose CA125 levels returned to normal limits } \\
\text { after operation } \\
\text { (n:54) }\end{array}$ & 32 & \multirow{2}{*}{0.015} & 108 & \multirow{2}{*}{0.015} \\
\hline $\begin{array}{l}\text { Patients whose CA125 levels did not return to normal } \\
\text { limits after operation } \\
\text { (n:78) }\end{array}$ & 18 & & 36 & \\
\hline \multicolumn{5}{|l|}{ Cut-off value for CA125 is $651 \mathrm{U} / \mathrm{ml}$} \\
\hline $\begin{array}{l}\text { Patients whose CA125 levels return to normal limits } \\
\text { after operation } \\
\text { (n:58) }\end{array}$ & 32 & & 89 & \multirow{2}{*}{0.000} \\
\hline $\begin{array}{l}\text { Patients whose CA125 levels did not return to normal } \\
\text { limits after operation } \\
\text { (n:61) }\end{array}$ & 17 & & 33 & \\
\hline
\end{tabular}




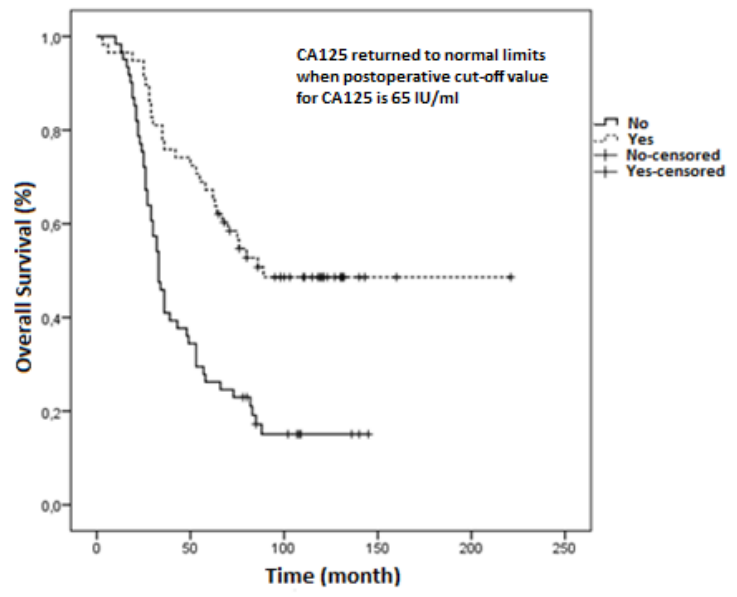

Figure 4. Overall survival analysis when postoperative cut-off value for CA125 is $65 \mathrm{IU} / \mathrm{ml}$.

\section{Discussion}

CA125 has been used as a marker in the diagnosis and follow-up of ovarian cancer patients for many years. In our study, we investigated the postoperative CA125 levels of the patients who had high levels at the time of diagnosis, and compared the patients whose CA125 serum levels returned to normal limits or not. When we took the cut-off value as $35 \mathrm{IU} / \mathrm{ml}$ and $65 \mathrm{IU} / \mathrm{ml}$, we found a significant difference in terms of disease free survival and overall survival between the groups of patients. With respect to recurrence/metastasis, there was a statistically significant difference between the patients who had normalized postoperative CA125 value and not only when considered for a CA125 cut-off value as 65 $\mathrm{IU} / \mathrm{ml}$.

The prognostic significance of preoperative CA125 value was investigated even in stage I ovarian cancer patients and found it to be a prognostic factor. It was observed that the properties of the ovarian tumor and the presence of ascites were the main determinants of CA125 elevation at the time of diagnosis [12,13]. In a study conducted by Cooper et al [14], high preoperative CA125 levels, which was defined as an independent risk factor for death, was associated with advanced stage and tumor grade in addition to ascites and serous histology. In a retrospective analysis involving about 90 patients, it was found that there was a significant correlation between postoperative CA125 value, and disease stage, tumor grade and overall survival [1].

There are many studies on the use of serum CA125 levels in operated ovarian cancer patients during the treatment period after surgery and during the follow-up period after treatment ends [2,5]. Regular measurement of not only serum CA125 but also HE4 values has a significant role in predicting postoperative recurrence $[15,16]$. For ovarian cancer, CA125 decrease observed during the administration of adjuvant chemotherapy and the time until the normalization of CA125 value were determined as the most important prognostic factors for both overall survival and disease-free survival $[17,18]$. It has been stated that both a decrease in CA125 level and also its decreased serum level may be an independent predictor of tumor recurrence in ovarian cancer patients [19]. Additionally, normalization of CA125 values during neoadjuvant chemotherapy was very important for both survival and evaluation of platinum sensitivity in locally advanced ovarian cancer patients who could not be operated at the time of diagnosis [7,20,21]. Besides, it was understood that the rate of CA125 decrease during chemotherapy cycles of recurrent ovarian cancer patients can be seen as a factor in predicting progression [22,23]. In advanced stage ovarian cancer, it was determined that following CA125 level and its kinetics may be not only predictive but also have prognostic significance [24]. In contrast to all these clinical benefits of CA125 tumor marker in epithelial ovarian cancer, it was concluded that preoperative CA125 is not a sufficient marker to predict whether cytoreductive surgery can be performed optimally or not. It is emphasized in these studies that preoperative CA125 is not enough and the tumor should always be evaluated together with other preoperative features [8-10].

Although there are numerous studies on CA125 value in ovarian cancer, there are not many studies evaluating this tumor marker perioperatively. Zwakman et al. [11] did a study on CA125 values in patients with ovarian cancer and they found that a decrease in serum CA125 level after primary cytoreductive surgery may have a role in predicting disease-specific survival. In this study, it was also concluded that the perioperative change in CA125 level, although not prospectively confirmed, may be an important marker in determining the residual tumor volume after surgery. In a study by Ghaemmaghami et al. [3] on patients with operated ovarian cancer, they investigated the patients' CA125 values at the time of diagnosis and compared them with the CA125 values two weeks after cytoreduction. They analyzed the relationship between the CA125 decrease detected in this period and whether the surgery was optimal or suboptimal, but could not find a significant relationship. In another study where CA125 value was compared before and after surgery; patients whose CA125 values returned to normal values within one month or showed a logarithmic decrease after treatment had better survival than those whose CA125 values returned to normal over a month or showed a non-logarithmic decrease [6]. Finally, in the retrospective analysis of 212 patients with high grade serous ovarian cancer, a 7-fold or more decrease in postoperative CA125 level was found to be associated with increased survival [4]. In present study, we compared CA125 values perioperatively in a similar way to these studies, but we investigated not only the decrease in CA125 level but also whether this tumor marker returned to normal levels or not.

\section{Conclusion}

In conclusion, basal CA125 level must be tested before operation in all patients with ovarian cancer. In patients with high basal CA125 value, prognosis can be determined by evaluating the decrease after surgery. Whether or not this value falls within normal limits may 
have some clinical significance in evaluating the relapse process. One of the limitations of this study is the limited number of cases. Further randomized trials with larger patient groups are essential to understand the perioperative role of serum CA125 levels in ovarian cancer patients. In addition, another limitation of the study is the low sensitivity and specificity of the CA125 marker in ovarian cancer. Therefore, more sensitive and specific tumor markers are needed in the early diagnosis and follow-up of patients with ovarian cancer.

\section{References}

1. Osman, N, O'Leary, N, Mulcahy, E, Barrett, N, Wallis, F, Hickey, K, et al. Correlation of serum CA125 with stage, grade and survival of patients with epithelial ovarian cancer at a single centre, Irish Medical Jornal, 2008, 101, 245-247.

2. Gundogdu, F, Soylu, F, Erkan, L, Tatli, O, Mavi, S, Yavuzcan, A, The role of serum CA-125 levels and CA-125 tissue expression positivity in the prediction of the recurrence of stage III and IV epithelial ovarian tumors (CA-125 levels and tissue CA-125 in ovarian tumors), Archives of Gynecology and Obstetrics, 2011, 283, 1397-1402.

3. Ghaemmaghami, F, Akhavan, S, Is postoperative CA125 level in patients with epithelial ovarian cancer reliable to guess the optimality of surgery? European Journal of Gynaecological Oncology, 2011, 32, 192-195.

4. May, T, Stewart, JM, Bernardini, MQ, Ferguson, SE, Laframboise, $\mathrm{S}$, Jiang, $\mathrm{H}$, et al, The prognostic value of perioperative, pre-systemic therapy CA125 levels in patients with high-grade serous ovarian cancer, International Journal of Gynecology \& Obstetrics, 2018 $140,247-252$.

5. Guo, N, Peng, Z, Does serum CA125 have clinical value for followup monitoring of postoperative patients with epithelial ovarian cancer? Results of a 12-year study, Journal of Ovarian Research $2017,10,14$

6. Yang, Z.J, Zhao, B.B, Li, L, The significance of the change pattern of serum CA125 level for judging prognosis and diagnosing recurrences of epithelial ovarian cancer, Journal of Ovarian Research, 2016, 9, 57.

7. Pelissier, A, Bonneau, C, Chéreau, E, DE LA MotteRouge, T, Fourchotte, V, Daraï, E, et al, Dynamic Analysis of CA125 Decline During Neoadjuvant Chemotherapy in Patients with Epithelial Ovarian Cancer as a Predictor for Platinum Sensitivity, Anticancer Research, 2016, 36, 1865-1871.

8. Arits, A.H, Stoot, J.E, Botterweck, A.A, Roumen, F.J, Voogd, A.C, Preoperative serum CA125 levels do not predict suboptimal cytoreductive surgery in epithelial ovarian cancer, International Journal of Gynecological Cancer, 2008, 18, 621-628.

9. Barlow, T.S, Przybylski, M, Schilder, J.M, Moore, D.H, Look, K.Y, The utility of presurgical CA125 to predict optimal tumor cytoreduction of epithelial ovarian cancer, International Journal of Gynecological Cancer, 2006, 16, 496-500.

10. Memarzadeh, S, Lee, S.B, Berek, J.S, Farias-Eisner, R, CA125 levels are a weak predictor of optimal cytoreductive surgery in patients with advanced epithelial ovarian cancer, International Journal of Gynecological Cancer, 2003, 13, 120-124.

11. Zwakman, N, van de Laar, R, Van Gorp, T, Zusterzeel, P.L, Snijders M.P, Ferreira, I, et al, Perioperative changes in serum CA125 levels: a prognostic factor for disease-specific survival in patients with ovarian cancer, Journal of Gynecologic Oncology, 2017, 28, e7.

12. Petri, AL, Høgdall, E, Christensen, IJ, Kjaer, S.K, Blaakaer, J, Høgdall C.K, Preoperative CA125 as a prognostic factor in stage I epithelial ovarian cancer, Journal of Pathology, Microbiology and Immunology, 2006, 114, 359-363.

13. Cramer, D.W, Vitonis, A.F, Welch, W.R, Terry, K.L, Goodman, A, Rueda, B.R, et al. Correlates of the preoperative level of CA125 at presentation of ovarian cancer. Gynecologic Oncology, 2010, 119, $462-468$

14. Cooper, B.C, Sood, A.K, Davis, C.S, Ritchie, J.M, Sorosky, J.I, Anderson, B, et al, Preoperative CA 125 levels: an independent prognostic factor for epithelial ovarian cancer, Obstetrics \&Gynecology, 2002, 100, 59-64.

15. Wang, Q, Wu, Y, Zhang, H, Yang, K, Tong, Y, Chen, L, et al, Clinica Value of Serum HE4, CA125, CA72-4, and ROMA Index for Diagnosis of Ovarian Cancer and Prediction of Postoperative Recurrence, Clinical Laboratory, 2019, 65(4).

16. Xu, X.R, Wang, X, Zhang, H, Liu, M.Y, Chen, Q, The clinical significance of the combined detection of serum Smac, HE4 and CA125 in endometriosis-associated ovarian cancer, Cancer Biomarkers, 2018, 21, 471-477.

17. Lee, M, Chang, M.Y, Yoo, H, Lee K.E, Chay, D.B, Cho, H, et al Clinical Significance of CA125 Level after the First Cycle of Chemotherapy on Survival of Patientswith Advanced Ovarian Cancer, Yonsei Medical Journal, 2016, 57, 580-587.

18. Tsuda, H, Hashiguchi, Y, Nakata, S, Deguchi, M, Negoro, S, Ishiko, $\mathrm{O}$, et al, The CA125 regression rate to predict overall survival differ between paclitaxel-containing regimen and nonpaclitaxel regimen in patients with advanced ovarian cancer, International Journal of Gynecological Cancer, 2002, 12, 435-437.

19. van Altena, A.M, Kolwijck, E, Spanjer, M.J, Hendriks, J.C, Massuger L.F, de Hullu, J.A, CA125 nadir concentration is an independent predictor of tumor recurrence in patientswith ovarian cancer: a population-basedstudy, Gynecologic Oncology, 2010, 119, 265-269.

20. Pelissier, A, Bonneau, C, Chéreau, E, de La MotteRouge, T, Fourchotte, V, Daraï, E, et al, CA125 kinetic parameters predict optimal cytoreduction in patients with advanced epithelial ovarian cancer treated with neoadjuvant chemotherapy, Gynecologic Oncology, 2014, 135, 542-546.

21. Le, T, Faught, W, Hopkins, L, Fung-Kee-Fung, M, Importance of CA125 normalization during neoadjuvant chemotherapy followed by planned delayed surgical debulking in patients with epithelial ovarian cancer, Journal of Obstetrics and Gynaecology Canada, 2008, 30, 665-670.

22. Wang, J, Liu, Y, Li, J, Lu, X, Prediction effects of serum CA125 decrease ratio during different cycles in relapsed ovarian cancer, Journal of Obstetrics and Gynaecology Research, 2019, 45, 1006-1011.

23. Yuan, Q, Song, J, Yang, W, Wang, H, Huo, Q, Yang ,J, et al, The effect of CA125 on metastasis of ovarian cancer: old marker new function, Oncotarget, 2017, 8, 50015-50022.

24. Colaković, S, Lukiç, V, Mitroviç, L, Jeliç, S, Susnjar, S, Marinkoviç, J. Prognostic value of CA125 kinetics and half-life in advanced ovarian cancer. The International Journal of Biological Markers, 2000, 15, 147-152.

http://edergi.cbu.edu.tr/ojs/index.php/cbusbed isimli yazarın CBU-SBED başlıklı eseri bu Creative Commons Alıntı-Gayriticari4.0 Uluslararası Lisansı ile lisanslanmıştır.

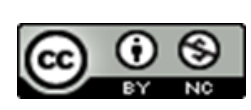

